\title{
Performa Ayam Ras Petelur pada Letak Cage Berbeda dalam Sistem Closed House di Global Buwana Farm
}

\author{
Performance of Laying Hens on Different Cage Position in Closed House System at Global Buwana Farm \\ D. T. Amijaya ${ }^{1}$, A. Yani $^{1}$, \& Rukmiasih ${ }^{1}$ \\ ${ }^{1}$ Departemen Ilmu Produksi dan Teknologi Peternakan, Fakultas Peternakan, \\ Institut Pertanian Bogor Jln. Agatis, Kampus IPB Darmaga, Bogor 16680 \\ Email koresponden author: doditisna28@gmail.com
}

\begin{abstract}
Air flow distribution, temperature, and humidity in the cage will differ from the inlet to the outlet. Microclimate difference in the cage at the inlet to the outlet can affect the production and quality of the eggs produced. The purpose of this research was to study the performance of laying hens on different location of cage (inlet, middle and outlet) in closed house system. In total 36 Lohmann hens were placed in each treatment including cage inlet, middle, and outlet. Traits measured were productive performance (hen day performance and egg weight) and egg qualities (haugh unit and egg shell thickness). The data were be analyzed using anova, tukey test, pearson correlation coefficient and completely randomized design. Result showed that here was very significant different on different location cage between temperature, relative humidity, and wind velocity. Cage inlet resulted better performance of laying hens compared to the middle and outlet cage.
\end{abstract}

Keywords: closed house, eqq quality, microclimate, production performance

\section{PENDAHULUAN}

Ayam petelur merupakan salah satu ternak unggas yang banyak dibudidayakan di Indonesia. Menurut Direktorat Jenderal Peternakan dan Kesehatan Hewan (2017), perkembangan populasi ayam ras petelur di Indonesia pada tahun 2017 sebesar 166723000 ekor sedangkan jumlah produksi telur yang dihasilkan adalah sebesar 1527100 ton. Peningkatan populasi ayam petelur saat ini belum diiringi dengan peningkatan produktivitas ayam petelur.

Perbaikan sistem pemeliharaan dapat dilakukan untuk meningkatkan produktivitas ayam petelur. Perkandangan menjadi salah satu aspek pokok yang perlu diperhatikan dalam pemeliharaan ayam petelur yang intensif dan efisien. Faktor perkandangan pun menjadi faktor yang memegang peranan penting dalam budidaya ayam. Hal ini dikarenakan kandang menjadi tempat aktivitas produksi bagi ternak, sehingga diperlukan lingkungan yang sesuai dan nyaman agar ternak dapat berproduksi dengan baik dan tidak terganggu. Sistem perkandangan tertutup (closed house) merupakan tipe kandang yang mempunyai pengaturan ventilasi udara yang baik dengan bantuan control panel otomatis. Sistem closed house memiliki ventilasi yang menggunakan tekanan yang dihasilkan oleh kipas (exhaust fan) dan cooling pad sebagai sistem pendinginnya.
Distribusi aliran udara, suhu, dan kelembaban dalam kandang akan berbeda dari titik inlet hingga outlet (exhaust fan). Menurut Yani (2014), Udara dingin dari cooling pad yang masuk ke kandang memiliki massa yang lebih besar sehingga pada saat didistribusikan sampai ke arah kipas (outlet), udara dingin semakin berkurang karena digunakan untuk mereduksi udara panas dalam kandang yang berasal dari tirai, dinding dan plafon.

Perbedaan lingkungan kandang yang meliputi suhu, kelembaban, dan kecepatan udara mengakibatkan perbedaan suhu efektif pada ayam petelur di titik inlet hingga outlet. Suhu yang berbeda akan mempengaruhi aktivitas produksi dan kualitas telur yang dihasilkan. Produksi telur sangat rentan terhadap masalah heat stress karena terkonsentrasi pemberian pakan dan ayam petelur kebanyakan dibesarkan pada cage yang ditumpuk dengan kepadatan penebaran yang tinggi (Tong et al. 2018). Killic dan Simsek (2013) menyebutkan bahwa, heat stress secara signifikan mengurangi produktivitas karena berkurangnya asupan pakan, menurunkan pakan konversi, kematian yang lebih tinggi, produksi telur berkurang, kualitas kerabang telur yang rendah, dan ukuran telur yang lebih kecil. Oleh karena itu, penelitian ini dilakukan untuk mengkaji performa ayam ras petelur pada letak cage yang berbeda dalam sistem perkandangan closed house. 


\section{MATERI DAN METODE}

\section{Waktu dan Tempat Penelitian}

Penelitian ini dilakukan di Global Buwana Farm, Cihideung Ilir, Bogor. Pengambilan data penelitian dimulai dari bulan April hingga Mei 2018 selama 32 hari.

\section{Bahan}

Ternak yang digunakan adalah ayam ras petelur strain Lohmann Brown sebanyak 108 ekor yang berumur 56 minggu. Sebanyak 36 ekor di tempatkan pada masingmasing perlakuan. Ayam tersebut merupakan ayam yang telah dipelihara pada sistem closed house di Global Buwana Farm. Pakan yang digunakan adalah pakan komersial ayam petelur produksi PT Japfa Comfeed dengan komposisi nutrisi pakan tersaji pada Tabel 1 .

Tabel 1. Kandungan nutrien pakan komersial

\begin{tabular}{lc}
\hline \multicolumn{1}{c}{ Nutrien } & Persentase (\%) \\
\hline Kadar air & Maks 12 \\
Protein kasar & Min 17 \\
Lemak kasar & Min 3 \\
Serat kasar & Maks 6 \\
Abu & Maks 14 \\
Kalsium & $3,5-4,0$ \\
Phospor & Min 0,45 \\
\hline
\end{tabular}

Sumber: Label pakan PT Japfa Comfeed

\section{Alat}

\section{Kandang}

Perlakuan yang diukur dalam kandang closed house terbagi menjadi 3 letak cage yang berbeda diantaranya cage depan yang berdekatan dengan cooling pad (inlet), cage berada di tengah dari panjang closed house (middle), dan cage belakang yang berdekatan dengan exhaust fan (outlet)
Setiap perlakuan terbagi menjadi 12 cage yang masing-masing cage berisi 3 ekor berukuran panjang $\times$ lebar $\times$ tinggi $(50 \mathrm{~cm} \times 35 \mathrm{~cm} \times 40 \mathrm{~cm})$. Layout ukuran kandang closed house dan posisi cage tampak atas ditampilkan pada Gambar 1 dan layout kandang closed house tampak depan ditampilkan pada Gambar 2. Letak cage depan (inlet) berjarak $5 \mathrm{~m}$ dari cooling pad. Letak cage di tengah berjarak $50 \mathrm{~m}$ dari titik cage inlet dan outlet, sedangkan letak cage di belakang (outlet) berjarak $5 \mathrm{~m}$ dari exhaust fan.

\section{Perlengakapan dan Analisis Telur}

Peralatan yang digunakan terdiri atas thermohigrometer, anemometer, tray, timbangan digital, jangka sorong, mikrometer kerabang telur, meja kaca, wadah, dan spatula.

\section{Prosedur}

\section{Pengukuran Mikroklimat}

Pengukuran suhu, kelembaban, dan kecepatan angin dilakukan selama 32 hari. Suhu dan kelembaban diukur menggunakan thermohigrometer. Pengukuran dilakukan pada pagi (07.00-08.00 WIB), siang (13.00-14.00 WIB), dan sore (17.00-18.00 WIB). Pengukuran kecepatan angin diukur setiap perlakuan dengan anemometer.

\section{Pengukuran Produksi Telur}

Pengukuran meliputi bobot telur dan hen day production dilakukan setiap hari di masing-masing letak cage yang berbeda. Pengukuran tersebut dilakukan selama 32 hari. Telur dikoleksi setiap harinya dari letak cage depan, tengah, dan belakang. Bobot telur dihitung berdasarkan hasil penimbangan telur setiap hari selama penelitian menggunakan timbangan digital. Hen day production dihitung berdasarkan jumlah telur yang dihasilkan dibagi dengan jumlah ayam yang ada di setiap letak cage dikalikan 100\%.

\section{Pengukuran Kualitas Telur}

Pengukuran dilakukan setiap minggunya pada masing-masing letak cage pada hari Minggu. Semua

\section{$110 \mathrm{~m}$}

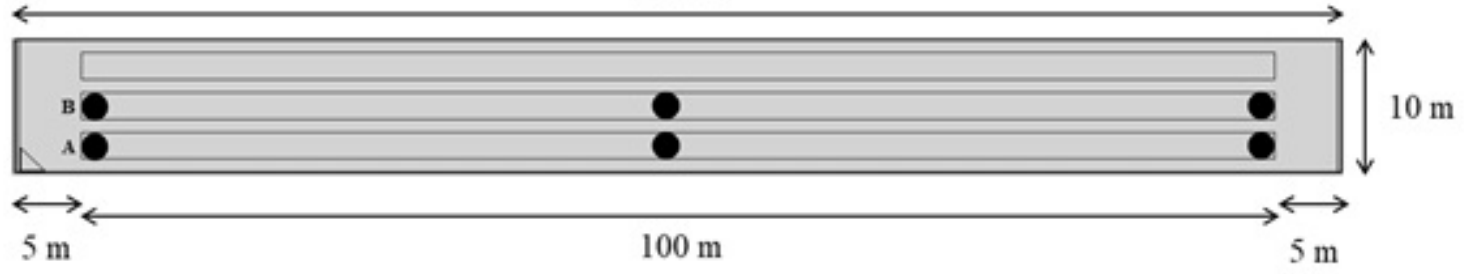

Gambar 1. Layout kandang tampak atas

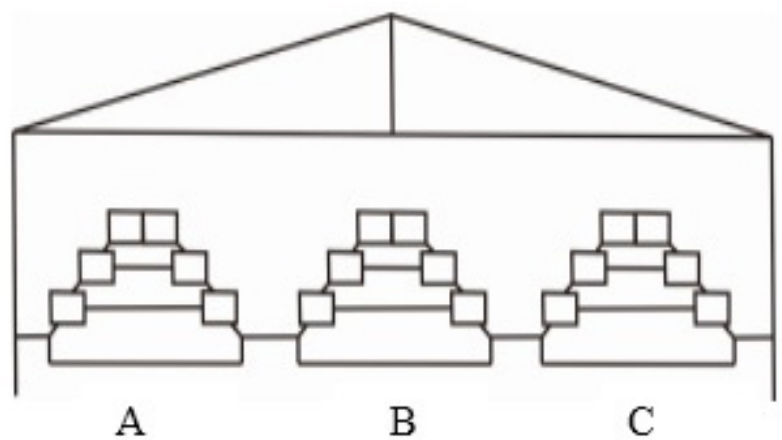

Gambar 2. Layout kandang tampak depan 
telur yang dihasilkan setiap hari Minggu dikoleksi untuk dilakukan pengukuran kualitas telur. Pengukuran dilakukan selama 4 minggu dengan mengukur kualitas eksterior (ketebalan kerabang) dan kualitas interior (Haugh Unit). Pengukuran tebal kerabang dilakukan dengan mengukur tebal kerabang tanpa selaput telur dengan alat Mitutoyo mikrometer. Perhitungan haugh unit dilakukan dengan pengukuran tinggi putih telur yang telah dipecahkan dan dihitung dengan rumus:

$$
\mathrm{HU}=100 \log \left(\mathrm{H}+7,57-1,7 \mathrm{~W}^{0,37)}\right.
$$

Keterangan:

$$
\mathrm{H} \quad=\text { tinggi putih telur kental }(\mathrm{mm}) \text {; dan }
$$$$
\mathrm{W} \quad=\text { bobot telur }\left(\mathrm{g} \text { butir }{ }^{-1}\right)
$$

\section{Rancangan dan Analisis Data}

Rancangan yang akan digunakan dalam penelitian ini adalah rancangan acak lengkap (RAL) dengan 3 perlakuan (kandang depan, tengah, dan belakang), masingmasing perlakuan sebanyak 36 ekor dengan pengukuran dilakukan selama 32 hari. Data yang diperoleh dianalisis menggunakan analisis ragam (ANOVA) untuk mengetahui pengaruh dari perlakuan. Model matematika yang digunakan sebagai berikut (Mattjik dan Sumertajaya 2013):

$$
Y i j=\mu+\rho i+\varepsilon i j
$$

Keterangan:

Yij = Nilai pengamatan performa ayam ras petelur perlakuan ke-i ulangan ke-j

$\mu=$ Nilai rataan umum hasil pengamatan

$\rho i=$ Pengaruh perlakuan ke-i ( $\mathrm{i}=$ cage depan; tengah; dan belakang)

ij = Pengaruh galat pada perlakuan ke-i ulangan ke-j

Jika perlakuan berpengaruh nyata, akan dilakukan uji lanjut menggunakan uji Duncan. Suhu efektif diperoleh dari hubungan suhu, kelembaban, dan kecepatan angin menggunakan persamaan empiris sebagai berikut:

$$
\mathrm{T}_{\mathrm{ef}}=0,811 \times\left((0,86 \mathrm{~T}+0,14 \mathrm{RH}) \mathrm{V}^{-0,132}\right)-2,74
$$

Keterangan:

$\mathrm{T}_{\text {ef }}=$ Suhu efektif $\left({ }^{\circ} \mathrm{C}\right)$

$\mathrm{T}=$ Suhu $\left({ }^{\circ} \mathrm{C}\right)$

$\mathrm{RH}=$ Kelembaban relatif $(\%)$

$\mathrm{V}=$ Kecepatan angin $\left(\mathrm{m} \mathrm{s}^{-1}\right)$

Data produksi telur (Hen day production dan bobot telur) dianalisis menggunakan model regresi linier berganda untuk mengetahui adanya hubungan produksi telur dengan mikroklimat serta besar pengaruhnya. Model matematika menurut Mattik dan Sumertajaya (2013) sebagai berikut:

$$
y=\beta_{0}+\beta_{1} X_{1}+\beta_{2} X_{2}+\beta_{3} X_{3}
$$

\section{Keterangan:}

$\mathrm{Y} \quad=$ Produksi telur (HDP dan bobot telur)

$\beta_{0}=$ Intersep

$\beta_{1}=$ Koefisien regresi produksi telur (y) terhadap suhu $(X 1)$ $\beta_{2}=$ Koefisien regresi produksi telur $(\mathrm{y})$ terhadap kelembaban $(X 2)$

$\beta_{3}=$ Koefisien regresi produksi telur (y) terhadap kecepatan angin $(X 3)$

\section{HASIL DAN PEMBAHASAN}

\section{Keadaan Umum Peternakan}

Peternakan Global Buwana Farm merupakan peternakan ayam layer yang berlokasi di Desa Cihideung Udik, Kecamatan Ciampea, Kabupaten Bogor. Peternakan ini berdiri pada tahun 2014. Lokasi peternakan berjarak sekitar $700 \mathrm{~m}$ dari pemukiman warga yang disekitarnya dikelilingi perkebunan sayur milik masyarakat.

Luas area peternakan mencapai 3 ha dilengkapi dengan berbagai sarana dalam mendukung proses produksi. Sarana tersebut meliputi jalur sanitasi, mess karyawan, gudang pakan, gudang koleksi telur, 5 kandang ayam petelur yaitu kandang closed house (A) dan kandang open house (B, C, D, dan E), dan mobil sebagai sarana transportasi.

Kandang yang digunakan dalam penelitian adalah kandang closed house. Kandang tersebut dibangun dengan daya tampung 13000 ekor. Closed house tersebut memiliki panjang kandang $110 \mathrm{~m}$ dan lebar kandang $10 \mathrm{~m}$ dengan ketinggian kandang $3 \mathrm{~m}$ dari lantai kandang. Fasilitas dalam kandang dilengkapi dengan 1 unit cooling pad, 7 unit exhaust fan, termometer, mesin pakan automatis, dan tempat minum berupa nipple.

\section{Mikroklimat Kandang}

Suhu, kelembaban, dan kecepatan angin merupakan lingkungan mikroklimat kandang yang berperan penting dalam mempengaruhi respon ternak. Pengukuran data mikroklimat tersebut dilakukan setiap hari selama 32 hari di setiap perlakuan yang berbeda di dalam closed house. Rataan pengukuran mikroklimat yang diperoleh disajikan pada Tabel 2.

Berdasarkan hasil analisis statistik menunjukkan kondisi mikroklimat di dalam closed house antara letak cage depan, tengah, dan belakang berbeda sangat nyata $(\mathrm{P}<0,01)$. Suhu lingkungan setiap cage akan lebih rendah pada pagi dan sore hari dibandingkan siang hari. Hasil pengukuran menunjukkan suhu kandang berbeda pada setiap perlakuan. Pengukuran pada waktu pagi hingga sore menunjukkan suhu akan meningkat dari letak cage di depan (inlet) hingga letak cage di belakang (outlet). Suhu dengan nilai terendah berada pada letak cage di depan $\left(25,6^{\circ} \mathrm{C}, 26,8^{\circ} \mathrm{C}\right.$, dan $\left.25,4{ }^{\circ} \mathrm{C}\right)$ pada pagi, siang dan sore hari sedangkan suhu tertinggi berada pada letak cage dibelakang $\left(28,2{ }^{\circ} \mathrm{C}, 31,5^{\circ} \mathrm{C}\right.$, dan $\left.28,8^{\circ} \mathrm{C}\right)$ pada pagi, siang dan sore hari.

Yani et al. (2014) menyatakan bahwa posisi dekat cooling pad lebih dingin karena merupakan daerah yang pertama menerima udara dingin yang masuk melalui cooling pad. Udara dingin yang masuk melalui cooling pad akibat dihisap oleh kipas pada ujung kandang menyebabkan udara tersebut langsung bergerak menuju kipas karena memiliki tekanan yang lebih besar. Kondisi ini menyebabkan udara dingin yang masuk melalui cooling pad bergerak terus ke arah kipas dan mendinginkan kandang sehingga semakin mendekati kipas, suhu 
Tabel 2. Rataan hasil pengukuran mikroklimat pada kandang closed house

\begin{tabular}{|c|c|c|c|c|c|}
\hline \multirow[t]{2}{*}{ Letak cage } & \multirow[t]{2}{*}{ Waktu } & \multicolumn{4}{|c|}{ Parameter } \\
\hline & & $\begin{array}{l}\text { Suhu } \\
\left({ }^{\circ} \mathrm{C}\right)\end{array}$ & $\begin{array}{c}\text { Kelembaban } \\
(\%)\end{array}$ & $\begin{array}{c}\text { Kecepatan angin } \\
\left(\mathrm{m} \mathrm{s}^{-1}\right)\end{array}$ & $\begin{array}{l}\text { Suhu Efektif } \\
\left({ }^{\circ} \mathrm{C}\right)\end{array}$ \\
\hline \multirow[t]{4}{*}{ Depan } & Pagi & $25,60 \pm 0,56$ & $91,00 \pm 2,13$ & $0,60 \pm 0,11$ & \\
\hline & Siang & $26,80 \pm 0,88$ & $86,00 \pm 3,94$ & $0,60 \pm 0,11$ & \\
\hline & Sore & $25,40 \pm 0,71$ & $90,00 \pm 3,40$ & $0,60 \pm 0,11$ & \\
\hline & Rataan & $25,80 \pm 0,45 \mathrm{c}$ & $89,00 \pm 3,14 a$ & $0,60 \pm 0,11 \mathrm{c}$ & 27,00 \\
\hline \multirow[t]{4}{*}{ Tengah } & Pagi & $27,60 \pm 0,67$ & $87,00 \pm 3,87$ & $0,80 \pm 0,07$ & \\
\hline & Siang & $30,20 \pm 0,79$ & $79,00 \pm 5,46$ & $0,80 \pm 0,07$ & \\
\hline & Sore & $27,90 \pm 0,79$ & $86,00 \pm 4,27$ & $0,80 \pm 0,06$ & \\
\hline & Rataan & $28,30 \pm 0,49 b$ & $84,00 \pm 3,36 \mathrm{c}$ & $0,80 \pm 0,06 \mathrm{~b}$ & 27,50 \\
\hline \multirow[t]{4}{*}{ Belakang } & Pagi & $28,20 \pm 0,82$ & $90,00 \pm 3,98$ & $1,30 \pm 0,19$ & \\
\hline & Siang & $31,50 \pm 0,90$ & $80,00 \pm 5,24$ & $1,30 \pm 0,20$ & \\
\hline & Sore & $28,80 \pm 0,66$ & $89,00 \pm 4,42$ & $1,30 \pm 0,20$ & \\
\hline & Rataan & $29,20 \pm 0,57 \mathrm{a}$ & $87,00 \pm 3,32 b$ & $1,30 \pm 0,19 \mathrm{a}$ & 26,40 \\
\hline
\end{tabular}

Keterangan: angka yang disertai huruf kecil yang berbeda pada kolom yang sama menunjukkan perbedaan yang sangat nyata $(\mathrm{P}<0,01)$

udaranya semakin lebih tinggi dibandingkan dengan posisi dekat cooling pad. Menurut Primaditya (2015), kandang tipe closed house mempunyai kelebihan seperti ternak tidak mudah stress akibat perubahan suhu yang ekstrim dari luar kandang dan kelembaban dan suhu dalam kandang yang dapat diatur. Kelembaban pada pagi dan sore hari lebih tinggi dibanding siang hari. Kelembaban yang ideal bagi ayam petelur menurut Yuwanta (2010) berkisar $60-70 \%$.

Tabel 2 menunjukkan letak cage di depan memiliki nilai kelembaban tertinggi $(91 \%, 86 \%$, dan 90\%) pada pagi, siang dan sore hari sedangkan kelembaban terendah pada letak cage di tengah $(87 \%, 79 \%$, dan $86 \%)$ pada pagi, siang dan sore hari. Secara keseluruhan kelembaban pada closed house tergolong tinggi bila dibandingkan dengan kelembaban yang dianjurkan. Tingginya kelembaban tersebut diakibatkan beberapa faktor diantaranya beroperasinya cooling pad, penguapan pada tubuh dan pernapasan ayam, dan penguapan bahan cair seperti air minum dalam kandang. Kondisi closed house dengan manajemen limbah feses ayam yang belum tepat menyebabkan kondisi kotoran basah dengan jumlah yang banyak. Hal tersebut diduga menjadi salah satu faktor penyebab tingginya kelembaban.

Kecepatan angin pada closed house berdasarkan Tabel 2 menunjukkan semakin jauh dari titik inlet kecepatannya semakin besar. Tong et al. (2018) menyatakan bahwa, kecepatan angin meningkat secara signifikan dari titik inlet menuju outlet pada sistem ventilasi tunnel. Letak cage di belakang memiliki kecepatan angin dengan rata-rata $1,3 \mathrm{~m} \mathrm{~s}^{-1}$ sedangkan letak cage di depan memiliki kecepatan dengan rata-rata $0,6 \mathrm{~m} \mathrm{~s}-1$. Tingginya kecepatan angin disebabkan beroperasinya exhaust fan yang bekerja dengan menghisap udara sehingga udara bergerak menuju ke tekanan yang lebih besar. Menurut Kecepatan angin berperan dalam proses pindah panas ayam ke udara dan upaya untuk membuang panas dalam kandang secara lebih cepat agar tidak terjadi penumpukan panas yang dapat menyebabkan kenaikan suhu kandang. Pengeluaran panas tubuh pada ayam melalui radiasi, konduksi, dan konveksi dengan pengeluaran terbesar melalui konveksi dan radiasi (Yani et al. 2014).

Suhu efektif terdiri dari faktor suhu lingkungan, kelembaban, dan kecepatan angin merupakan indeks yang dikembangkan untuk memperkirakan tekanan panas hewan dengan efek kecepatan udara (Bjerg et al. 2017). Berdasarkan Tabel 2 menunjukkan suhu efektif pada cage depan, tengah, dan belakang memiliki nilai sebesar 27, 27,5 dan $26,4^{\circ} \mathrm{C}$. Suhu efektif pada cage tengah memiliki nilai yang lebih besar dibanding lainnya, sedangkan pada cage belakang memiliki nilai yang lebih rendah. Adanya kecepatan aliran udara yang tinggi pada titik outlet mampu menurunkan suhu dan heat stress pada titik tersebut (Tong et al. 2018). Kecepatan aliran udara akan membantu ayam untuk melepaskan panas tubuhnya melalui konveksi yang ditimbulkan dari efek aliran udara.

\section{Produksi Telur}

Produksi yang diukur meliputi hen day production dan bobot telur. Hasil rataan pengaruh letak cage yang berbeda terhadap performa produksi telur disajikan pada Tabel 3. Hasil analisis statistik menunjukkan adanya perbedaan yang sangat nyata pada letak cage terhadap hen day production dan bobot telur $(\mathrm{P}<0,01)$. Berdasarkan standar Lohmann Tierzucht (2010) ayam petelur strain Lohmann Brown umur 56-60 minggu memiliki produksi telur rata-rata sebesar $86,12 \%$.

Hen day production merupakan salah satu peubah yang diukur untuk mengetahui ukuran tingkat produksi telur ayam. Hasil analisis statistik menunjukkan HDP pada letak masing-masing letak cage berbeda sangat nyata. Rataan produksi telur pada letaks cage depan sebesar $86,15 \pm 1,80 \%$ memiliki nilai yang sesuai dengan standar Lohmann, namun dibandingkan dengan perlakuan lainnya nilai produksi telur lebih rendah pada cage tengah sebesar $70,70 \pm 4,09 \%$. 
Tabel 3. Rataan pengaruh perlakuan terhadap performa produksi

\begin{tabular}{lccc}
\hline Peubah & \multicolumn{3}{c}{ Letak Cage } \\
\cline { 2 - 4 } & Depan & Tengah & Belakang \\
\hline $\begin{array}{l}\text { Hen day } \\
\text { production (\%) }\end{array}$ & $86,15 \pm 1,80 \mathrm{a}$ & $70,70 \pm 4,09 \mathrm{c}$ & $81,85 \pm 4,07 \mathrm{~b}$ \\
$\begin{array}{l}\text { Bobot telur } \\
\text { (g butir }{ }^{-1} \text { ) }\end{array}$ & $66,42 \pm 2,38 \mathrm{a}$ & $64,15 \pm 2,18 \mathrm{~b}$ & $64,46 \pm 2,73 \mathrm{~b}$ \\
\hline
\end{tabular}

Keterangan: angka yang disertai huruf kecil yang berbeda pada kolom yang sama menunjukkan perbedaan yang sangat nyata $(\mathrm{P}<0,01)$

Hal ini disebabkan oleh faktor suhu yang tinggi pada cage tengah menyebabkan konsumsi pakan menjadi rendah yang berakibat pada produksi telur yang dihasilkan menjadi rendah. Setiawati (2014) menyatakan HDP yang tinggi umumnya diiringi dengan konsumsi pakan yang mencukupi kebutuhan hidup pokok dan produksi.

Hasil analisis statistik menunjukkan bobot telur pada letak cage depan berbeda sangat nyata dengan letak cage tengah dan belakang. Rataan bobot telur pada masing-masing letak cage baik pada cage depan memiliki nilai $66,42 \pm 2,38 \mathrm{~g}$ butir $^{-1}$, cage tengah memiliki nilai $64,15 \pm 2,18 \mathrm{~g} \mathrm{butir}^{-1}$, dan cage belakang memiliki nilai $64,46 \pm 2,73 \mathrm{~g} \mathrm{butir}^{-1}$. Nilai bobot telur pada cage depan memiliki nilai yang sesuai dengan standar Lohmann Tierzucht (2010) dengan bobot telur rata-rata sebesar 66,9 g butir ${ }^{-1}$.

Hasil statistik menunjukkan nilai bobot telur pada cage tengah dan belakang berbeda dari bobot telur pada cage depan yang lebih besar bobotnya. Poultry Hub (2017) menyatakan bahwa, ketika suhu meningkat di atas $24^{\circ} \mathrm{C}$, kualitas cangkang dan berat telur akan berkurang. Menurut Yuwanta (2010) bobot telur dipengaruhi oleh beberapa hal diantaranya genetik, umur ternak, dan suhu lingkungan.

\section{Kualitas Telur}

Lingkungan mikroklimat kandang dapat mempengaruhi kualitas telur yang dihasilkan. Hasil rataan pengaruh letak cage yang berbeda terhadap kualitas telur disajikan pada Tabel 4. Pengujian kualitas telur secara visual akan menunjukkan interaksi antara perlakuan terhadap tinggi putih telur, haugh unit, dan tebal kerabang (Komalasari 2014).

Haugh unit (HU) merupakan salah satu parameter kualitas interior telur yang dihitung berdasarkan tinggi albumen dan bobot telur (Keener et al. 2006). Semakin tinggi nilai $\mathrm{HU}$ menunjukkan semakin tinggi kualitas telur dan semakin baik kualitas albuminnya. Perbedaan mikroklimat kandang masing-masing letak cage yang berbeda tidak mempengaruhi nilai haugh unit. Nilai HU pada masing-masing letak cage baik pada bagian depan,

Tabel 4. Rataan pengaruh perlakuan terhadap kualitas telur

\begin{tabular}{lccc}
\hline \multicolumn{1}{c}{ Peubah } & \multicolumn{3}{c}{ Letak Cage } \\
\cline { 2 - 4 } & Depan & Tengah & Belakang \\
\hline Haugh unit (HU) & $95,62 \pm 7,76$ & $90,63 \pm 14,03$ & $87,48 \pm 13,79$ \\
Kualitas HU & AA & AA & AA \\
Tebal kerabang & $0,36 \pm 0,02$ & $0,35 \pm 0,03$ & $0,35 \pm 0,03$ \\
$(\mathrm{~mm})$ & & & \\
\hline
\end{tabular}

tengah, dan belakang dikategorikan ke dalam kualitas AA yaitu >72 menurut USDA (1964). USDA mengelompokkan nilai Haugh unit menjadi beberapa kategori yaitu AA untuk nilai $\mathrm{HU}>72$, A untuk nilai $\mathrm{HU}$ 60-72, B untuk nilai HU 31-60 dan $\mathrm{C}$ untuk nilai $\mathrm{HU}<31$. Waktu penyimpanan dan kondisi penyimpanan merupakan faktor yang mempengaruhi tinggi albumen pada telur (Silverside dan Scott 2001).

Terbentuknya kerabang telur diakibatkan karena adanya ion kalsium dan ion karbonat. Tebal kerabang erat kaitannya dengan konsentrasi kalsium dalam pakan karena kerabang telur didominasi oleh komponen kalsit $(\mathrm{CaCO} 3)$ dan sedikit sodium, potasium, serta magnesium (Suprijatna et al. 2005). Nilai rataan tebal kerabang pada masing-masing cage depan, tengah, dan belakang kisaran 0,35-0,36 $\mathrm{mm}$, nilai tersebut masih tergolong normal yang berada pada kisaran 0,33-0,38 mm (Yuwanta 2010). Setiawati (2014) menyatakan, suhu tinggi dapat menyebabkan ayam melakukan panting sehingga terjadi penurunan konsentrasi $\mathrm{CO} 2$ di dalam darah yang dapat mempengaruhi proses pembentukan kerabang. Hasil penelitian Komalasari (2014) menunjukkan pada ayam ras petelur strain Lohmann pada suhu 28 oC mulai banyak mengalami panting.

\section{KESIMPULAN}

Suhu, kelembaban, dan kecepatan angin pada kandang closed house tidak sama dari titik inlet hingga outlet. Ayam ras petelur pada letak cage di depan (inlet) memiliki performa produksi yang lebih baik dan kualitas telur yang sesuai dengan standar bila dibandingkan dengan letak cage lainnya.

\section{DAFTAR PUSTAKA}

USDA (United States Department of Agriculture). 1964. Egg Grading Manual. Federal Crop Insurance Corporation, Washington DC.

Ditjennak (Direktorat Jenderal Peternakan dan Kesehatan Hewan). 2017. Statistik Peternakan dan Kesehatan Hewan. Jakarta (ID) : Direktorat Jenderal Peternakan dan Kesehatan Hewan.

Bjerg, B., L. Rong, \& G. Zhang. 2017. Computational prediction of the effective temperature in the lying area of pig pens. Computers and Electronics in Agriculture. 149: 71-79.

Keener, KM., J. B. McAvoy Foegeding, P. A. Curtis, K. E. Anderson, \& J. A. Osborne. 2006. Effect of testing temperature on internal egg quality measurement. Poultry Science Association. 85:550-555.

Killic, I., E. Simsek. 2013. The effect of heat stress on egg production and quality of laying hens. Journal of Animal Veterinary Advances. 12(1):42-47.

Komalasari, L. 2014. Dampak suhu tinggi terhadap respons fisiologi, profil darah dan performa produksi dua bangsa ayam berbeda. Tesis. Bogor (ID): Institut Pertanian Bogor.

Lohman Tierzucht. 2010. Lohmann brown-classic layers product performance. [Internet]. [diunduh 2017 November 28]. Tersedia pada: http://www.ltz.de/. 
Mattjik, A. A., Sumertajaya IM. 2013. Perancangan Percobaan dan Aplikasi SAS dan Minitab. Cetakan ke4. IPB Pr, Bogor.

Primaditya, F. M., Hidanah S, \& Soeharsono. 2015. Analisis pendapatan dan produktivitas ayam petelur sistem "close house" dengan penggunaan mesin pakan otomatis dan manual di Kuwik Farm Kecamatan Badas Pare. Agroveteriner. 3(2):99-106.

Poultry Hub. 2017. Climate in poultry house [Internet]. [diunduh 2018 Desember 03]. Tersedia pada: http:// www.poultryhub.org.

Setiawati, T. 2014. Performa produksi dan kualitas telur ayam petelur pada sistem litter dan cage dengan suhu kandang berbeda. Jurnal Ilmu Produksi dan Teknologi Peternakan. 4(1):197-203.

Silverside, D., G. B. Scott. 2001. House, husbandry and welfare of poultry. National Agricultural Library, United State of America.

Suprijatna, E. U., R. Atmomarsono, \& Kartasudjana. 2005. Ilmu Dasar Ternak Unggas. Penebar Swadaya, Jakarta.

Tong, X., S. W. Hong, \& L. Zhao. 2018. CFD modelling of airflow pattern and thermal environment in commercial manure-belt layer house with tunnel ventilation. Biosystems engineering. 30(1):1-19.
Tong, X., S. W. Hong, \& L. Zhao. 2018. Using CFD simulations to develop an upward airflow displacement ventilation system for manure-belt layer house to improve the indoor environmet. Biosystems engineering. 30(1):1-15.

Yani, A. 2014. Pemodelan pindah panas pada budidaya ayam broiler menggunakan kandang sistem tertutup di daerah brriklim tropika basah. Disertasi. Bogor (ID): Institut Pertanian Bogor.

Yani, A., H. Suhardiyanto, Erizal, \& B. P. Purwanto. 2014. Analysis of air temperature distribution in a closed house forbroiler in wet tropical climate. Med Pet. 37(2):87-94.

Yani, A., H. Suhardiyanto, Erizal, \& B. P. Purwanto. 2014. Design of stocking density of broilers for closed house in wet tropical climates. Med Pet. 37(1):17-23.

Yuwanta, T. 2010. Telur dan Kualitas Telur. Universitas Gajah Mada Pr, Yogyakarta. 